\title{
The Research on Optimizing Training Program for Master Graduate Students in Sports Science under National Program
}

\author{
On the Basis of Comparative Analysis of 13 National Sports Colleges
}

\author{
Yuanxiang Liu \\ Shandong Sport University \\ Jinan, China 250102
}

\begin{abstract}
As a programmatic document for postgraduate training, the postgraduate training program is essential for the quality of postgraduate training. In the context of that "fitness" and "sports industry" are promoted to the national strategy, using literature, investigation and mathematical statistics methods, this paper makes a comparative analysis on the Chinese $13 \mathrm{PE}$ college of physical education postgraduates training program on the basis that recognizing physical education high-level talent requirement and supply is a disconnect problem. It points out the problems that exist in the training program such as training objectives of convergence, quality standards vague, training methods and other single issue, as well as puts forwards some suggestions: docking needs of the community, according to sports science disciplines amendment postgraduate training programs, enrich training methods and so on.
\end{abstract}

Keywords-training program; Physical Education; social needs; national strategy

\section{INTRODUCTION}

In April 2013, Ministry of Education, National Development and Reform Commission and Ministry of Finance jointly issued Opinions on Deepening the Reform of Postgraduate Education, which points out that postgraduate education still cannot fully meet the diversified demands of economic and social development, and there is still a big gap compared with international advanced level in training quality. In 2009 and 2010, the employment rate of postgraduates was not higher than undergraduates. [1] There are two reasons: first, the training objective cannot satisfy the needs of society; second, the training quality cannot meet the requirements of jobs. The postgraduate training program is the overall design blueprint for postgraduate training, a programmatic document for teaching work, a main basis of teaching activities and teaching management of postgraduates, which determines the training quality and level of postgraduates.

Based on this condition, research on how to comply with the requirements of documents of State Council and Ministry

Foundation Program: Shandong Postgraduate Education Innovation Program (SDYC5015). of Education, conform to the social needs of "National Fitness Program", "Sports Industry" and "Healthy China" strategy, optimize the training program of postgraduates of physical education, adjust research direction and promote the reform of postgraduate training mechanism, improve the training quality of postgraduates of physical education, combine the supply of high-level talents in university with social demands, which has great theoretical significance and practical value.

\section{THE CONNOTATION OF SPORTS SCIENCE TRAINING PROGRAM FOR POSTGRADUATES UNDER THE NATIONAL STRATEGY}

The postgraduate training program is the overall design blueprint for postgraduate training, a reflection of school work of the whole idea in talent training, a concentrated reflection of teaching thoughts and teaching ideas, a main basis of teaching activities and teaching management of postgraduates, which determines the training quality and level of postgraduates.

The postgraduate training program is the programmatic document for postgraduate teaching work, a reflection of school work of the whole idea in talent training, definite the training target of postgraduates. Students should master the breadth and depth of basic knowledge of the major and related subjects, and has the ability to engage in professional scientific research in this major or undertake professional technical work independently, and come up with the specific requirements and specific provisions for training postgraduates. The training objectives, basic requirements, research directions, curriculum setting, scientific research training and practical training, quality standards and so on are stipulated.

III. TALENT REQUIREMENT ANALYSIS OF

POSTGRADUATES OF PHYSICAL EDUCATION UNDER THE NATIONAL STRATEGY

In October 2014, the State Council issued the Opinions on Accelerating the Development of Sports Industry and Promoting Sports Consumption, which promoted national 
fitness and the development of sports industry as a national strategy, and put forward that "university should focus on training operation and management of sport, creative design, scientific research, intermediary and other professionals, and encourage to input and train mixed mode sports industry talents in many ways and channels, support the retired athletes accept re-employment training." In October 2016, the Central Committee of CPC issued the Healthy China 2030 Program Outline and pointed out that the contradiction between the overall lack of supply and demand and the growth of demand was still outstanding, and the coordination between health area development and economic and social development needs to be strengthened, and major and longterm problems in relation to health should be solved in overall planning at the national strategic level. How to ensure the implementation of these national strategies and the effective supply of high-level talents in related fields of sports is more vital.

\section{A. Scientific Fitness Field}

With the improvement of living standards and the residents' awareness of fitness, the fitness demand has gradually increased. However, how to guide the residents to have a scientific fitness and eliminate fitness misunderstandings is important for the government and professional personnel training is particularly urgent and important. At present, the demand gap of fitness trainer and health management personnel in the market is still large. National Development and Reform Commission and other 10 ministries jointly issued the Notice on Accelerating and Promoting the Project Construction of Health and Pension Services and pointed out that we should strengthen the exchange of personnel training, and colleges and universities should set up relevant majors and curriculums for health and pension services to intensify the efforts of talents training.

\section{B. Sports Industry Field}

The confirmation of national development strategy of sports industry makes the concept of sports industry become popular rapidly in China. The successful bidding of Winter Olympic Games and the cancellation of the examination and approval authority of commercial sports have stimulated Chinese sports industry to experience an unprecedented upsurge. The core of industry development is talent. While sports industry welcomes the opportunities of historical development, the domestic sports colleges and universities or majors has not changed in personnel training of sports industry, and the problem of scarcity of talent has also emerged.

\section{Sports Rehabilitation Field}

Aiming at the contradiction between the shortages of medical resources and increasing medical demand in our country, sports rehabilitation is an effective way to solve this problem. Through sports guidance and "sports prescription" promotion, we can exert the positive effects of physical exercise on disease prevention and health promotion. However, the domestic sports rehabilitation industry is still in its starting, and the market demand is large and the supply of professionals is insufficient.

\section{Capital Operation Field}

Capital operation is an inexorable trend of sports industry development in China. Our country has repeatedly issued documents to encourage broadening the investment and financing channels of sports industry, setting up investment funds and special funds for sports industry, supporting qualified sports products, services and other enterprises listed, supporting qualified enterprises to issue non-financial debt financing instruments, such as enterprise bonds, corporate bonds, short-term financing bonds, medium-term notes, collection of bills and private equity debt of small and medium enterprises. Now sports industry doesn't lack money or projects, mainly the talents. As the general manager Bian Guangming of Zhongti Dingxin Funds puts: at present, many domestic sports groups are troubled by the lack of crossborder talents of knowing the sports itself and the operation of capital.

\section{E. Sports Brokerage Field}

With the development of sports commercialization and the endless appearance of sports stars, the sports sponsorship industry is like a raging fire, and sports brokers are playing a more and more important role. However, the sports broker market is in its starting and commercialization degree is low, and brokerage activities show a trend of immaturity.

\section{SituATION ANALYSIS OF SPORTS SCIENCE TRAINING PROGRAM FOR POSTGRADUATES}

This thesis analyzes the sports science training program for postgraduates in 13 institutes of physical education in China, and finds that the training program covers these basic contents, such as subject introduction, training objectives and requirements, training methods, curricula setting, and thesis and so on. There are two institutes which develop training program in accordance with the first level of discipline: Capital University of Physical Education and Sports and Jilin Sport University. The other 11 institutes develop in accordance with the second level and third level of disciplines to identify the research area, and these disciplines are sports humanities and sociology, human movement science, theory of sports pedagogy and training and science of ethnic traditional sports, which leads to that the knowledge structure of postgraduates is too specialized and the scope of knowledge is too narrow. Relative single training style affects the cultivation of students' innovation consciousness and ability, and makes students lack the independent spirit, critical thinking and practical ability.

\section{A. The Training Objective Is Misplaced and the Content Is Convergent}

The training objective refers to the specific standards and requirements for the physical and mental development of the educators in various educational institutes or discipline at all levels. Through the research and analysis of the training target of 13 sports institutes, we can find that the expression 
of training target is relatively abstract and the content is relatively abundant. In addition to the same requirements of ideological and political, the requirements of professional knowledge and practical ability are basically the same, and the training of teaching, scientific research and management personnel is without distinctions in physical discipline. It is an indisputable fact that the training quality for postgraduates is declining because of the misplacement of training objective and the excessively broad training orientation. The training program of Capital University of Physical Education and Sports and Wuhan Institute of Physical Education indicates that they will cultivate the practical personnel to meet social demands, but Shandong Sport University aims at cultivating high-level inter-disciplinary talents, and the other 10 institutes choose to cultivate research-based talents. (See "Table I") The diversity of social demands and the singleness of current training objective for postgraduates result in the obvious separation between the high level talents of sports science training program for postgraduates and the high level talents of social demands.

\section{B. Research Direction Is Obsolete}

The research direction is the leading research area of a research organization or researcher in a certain historical period. The research direction of training program is closely related to the research direction of master's tutor, which has an important impact on curriculum setting, training of scientific research and employment direction. Through the analysis of training program of 13 sports institutes, we find that except for Jilin Sport University and Shandong Sport University, the other 11 institutes have introduced 3-10 different research directions in the training program. In addition to the lack of unity in setting standards of the research direction, we analyze the research direction established by institutes and social demands and the hot and difficult problems of current research, and find that some research directions are obsolete and the dynamic adjustment is not timely.

\section{Cultivation Mode Is Single}

In the mode of training, course teaching is the main way and students are less involved in the practice. The guidance way is dominated by single-tutor system, but the case analysis and social surveys are relatively less. (See "Table II") The relatively single training mode limits the subjective initiative and independent creativity of postgraduate training.

\section{The Remarkable Distinctions of Curriculum Setting}

The curriculum setting of training program carries out overall planning and comprehensive arrangements for teaching and various learning activities based on the training objectives and requirements. The training units have more independent power to the curriculum setting and the curriculum learning has the strongest controllability in postgraduate training. [4] In terms of the total amount of curriculum, all the colleges and universities require 32-36 credits of curriculum to graduate, in other words, about 1416 curriculums. The curriculum setting includes public degree courses, basic degree courses, professional degree courses, professional optional courses, interdisciplinary or cross-major courses, practice, scientific research training and academic lectures. There are great differences in curriculum setting and system structure of institutes. The lack of makeup course makes it difficult to eliminate the origin differences of different professional students training. To cultivate students' sports special skills, Capital University of Physical Education and Sports, Jilin Sport University and Shandong Sport University open the selected courses. (See "Table III") According to the training plan formulated by the second level discipline, the relationship between different majors is cut off and it is adverse to the construction of knowledge system of sports science.

TABLE I. A LIST OF SPECIFIC REQUIREMENTS OF 13 SPORTS InSTITUTES TRAINING PROGRAM FOR POSTGRADUATES

\section{Training Target}

\begin{tabular}{|c|c|c|}
\hline & & \\
\hline $\begin{array}{l}\text { Beijing } \\
\text { University }\end{array}$ & Sport & $\begin{array}{l}\text { 1. Political thought, moral trait } 2 \text {. Professional } \\
\text { knowledge ability } 3 \text {. Foreign language aptitude, data } \\
\text { collection capability } 4 \text {. Healthy body } 5 \text {. Knowledge } \\
\text { about sports }\end{array}$ \\
\hline $\begin{array}{l}\text { Shanghai } \\
\text { University } \\
\text { Sport }\end{array}$ & of & $\begin{array}{l}\text { 1. Political thought, academic moral 2.Professional } \\
\text { knowledge, innovation consciousness, scientific } \\
\text { research ability } 3 \text {. Foreign language aptitude } 4 . \\
\text { Practical ability, sound in body and mind }\end{array}$ \\
\hline $\begin{array}{l}\text { Wuhan } \\
\text { University }\end{array}$ & Sports & $\begin{array}{l}\text { 1. Political thought, legal consciousness } 2 \text {.Professional } \\
\text { knowledge, practical ability } 3 \text {. Foreign language } \\
\text { aptitude, computer capacity } 4 \text {.Specific sport skills and } \\
\text { training theories } 5 \text {. Fitness theory, health knowledge } 6 \text {. } \\
\text { Be in strong health } 7 \text {. Application-oriented talent }\end{array}$ \\
\hline $\begin{array}{l}\text { Tianjin } \\
\text { University } \\
\text { Sport }\end{array}$ & of & $\begin{array}{l}\text { 1. Political thought, moral trait } 2 \text {. Team spirit, } \\
\text { professional knowledge } 3 \text {. Practical ability } 4 \text {. Foreign } \\
\text { language aptitude } 5 \text {.Fitness }\end{array}$ \\
\hline $\begin{array}{l}\text { Guangzhou } \\
\text { University }\end{array}$ & u Sport & 1. Moral quality 2. Practical ability \\
\hline $\begin{array}{l}\text { Chengdu } \\
\text { Institute }\end{array}$ & Sport & $\begin{array}{l}\text { 1. Patriotic thought, moral quality } 2 \text {. Professional } \\
\text { knowledge, innovation ability, communication and } \\
\text { cooperation ability } 3 \text {. Foreign language aptitude } 4 . \\
\text { Love sports }\end{array}$ \\
\hline $\begin{array}{l}\text { Xi'an Pl } \\
\text { Education } \\
\text { University }\end{array}$ & & $\begin{array}{l}\text { 1. Political thought 2. Professional knowledge, } \\
\text { practical ability 3. Foreign language aptitude } 4 . \\
\text { Computer capacity }\end{array}$ \\
\hline $\begin{array}{l}\text { Shenyang } \\
\text { University }\end{array}$ & Sport & $\begin{array}{l}\text { 1. Political thought 2. Academic moral } 3 \text { Professional } \\
\text { knowledge theories } 4 \text {. Foreign language aptitude } 5 \text {. } \\
\text { Computer capacity, data collection capability } 6 \text {. } \\
\text { Specific sport skills } 7 \text {. Sound in body and mind }\end{array}$ \\
\hline $\begin{array}{l}\text { Shandong } \\
\text { University }\end{array}$ & Sport & $\begin{array}{l}\text { 1. Professional knowledge 2.Moral cultivation } 3 . \\
\text { Practical ability } 4 \text {. Foreign language aptitude } 5 \text {. Inter- } \\
\text { disciplinary talent }\end{array}$ \\
\hline $\begin{array}{l}\text { Capital } \\
\text { University } \\
\text { Physical } \\
\text { Education } \\
\text { Sports }\end{array}$ & and & $\begin{array}{l}\text { 1. Political thought, professional ethics } 2 \text {. Professional } \\
\text { knowledge } 4 \text {. Professional skill } 5 \text {. Foreign language } \\
\text { aptitude v computer capacity } 6 \text {. Sound in body and } \\
\text { mind } 7 \text {. Application-oriented talent }\end{array}$ \\
\hline $\begin{array}{l}\text { Jilin } \\
\text { University }\end{array}$ & Sport & $\begin{array}{l}\text { 1. Political thought } 2 \text {. Professional knowledge and } \\
\text { basic skills } 3 \text {. Innovation ability } 4 \text {. Foreign language } \\
\text { aptitude } 5 \text {. Computer capacity }\end{array}$ \\
\hline $\begin{array}{l}\text { Harbin } \\
\text { University }\end{array}$ & & $\begin{array}{l}\text { 1. Political thought 2. Professional knowledge } 3 . \\
\text { Practical ability } 4 \text {. Professional skill 5. Strong physique }\end{array}$ \\
\hline $\begin{array}{l}\text { Nanjing } \\
\text { Institute }\end{array}$ & Sport & $\begin{array}{l}1 \text { Political thought } 2 . \text { Professional ethics } 3 . \\
\text { Professional skill 4. Innovation ability } 5 \text {. Foreign } \\
\text { language aptitude } 6 \text {. Fitness }\end{array}$ \\
\hline
\end{tabular}


TABLE II. A List OF SPECIFIC TRAINING WAYS OF 13 SpORTS INSTITUTES TRAINING PROGRAM

\begin{tabular}{|c|c|c|c|c|}
\hline $\begin{array}{c}\text { Tutorial } \\
\text { Responsi } \\
\text { bility } \\
\text { System }\end{array}$ & $\begin{array}{c}\text { Social } \\
\text { Surveys }\end{array}$ & $\begin{array}{c}\text { Case } \\
\text { Analys } \\
\text { is }\end{array}$ & $\begin{array}{c}\text { Extracurri } \\
\text { cular } \\
\text { Teaching } \\
\text { Research } \\
\text { Practice }\end{array}$ & $\begin{array}{c}\text { Acade } \\
\text { mic } \\
\text { Lectur } \\
\text { e }\end{array}$ \\
\hline
\end{tabular}

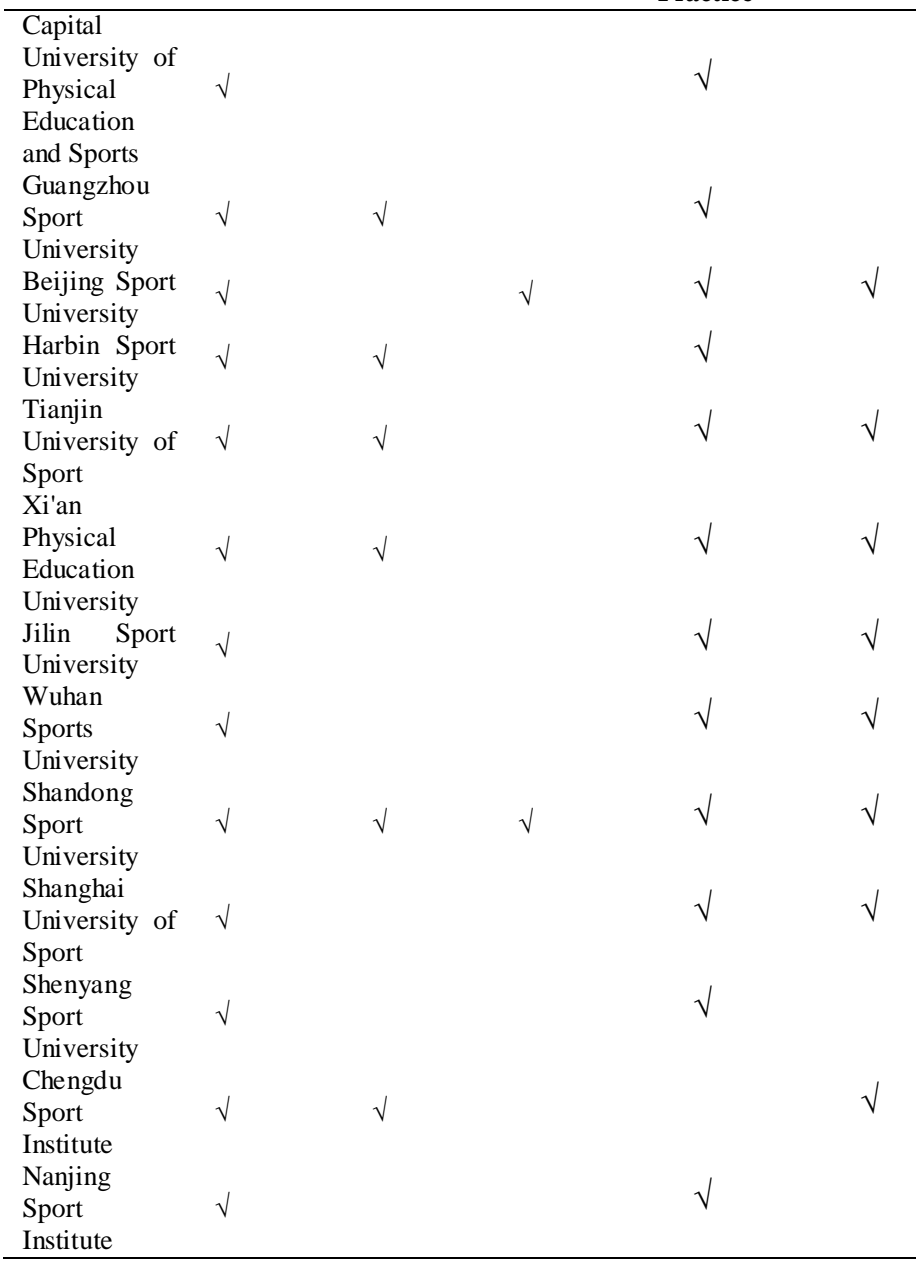

\section{E. The Lack of Quality Standard}

Through comparing and analyzing the postgraduate training program of 13 sports institutes, we find that most sports institutes are relatively ambiguous and vague in the training quality standard, and they lack explicit requirements and the quality standard is not uniform. In addition to practicing credits, other requirements are not specific and even lost. Some institutes make requirements on scientific research workload, participating in academic activities, paper publication and thesis. For example, Wuhan Institute of Physical Education, Chengdu Sport Institute and Guangzhou Sport University require that postgraduates should attend academic activities and seminars no less than 6 times. Shanghai University of Sport, Wuhan Institute of Physical Education, Capital University of Physical Education and Sports, Harbin Sport University, Shenyang Sport University and Nanjing Sport Institute require that postgraduates should publish at least one academic paper in academic journals before graduation.

\section{F. The Lack of Supervision In Practice}

Practice is a relatively simple expression in postgraduate training program of institutes, and the 13 sports institutes make requirements on practice link in the training program. The basic form includes education and training practice, social practice, academic practice and so on. However, the relative requirements are low and they lack the detailed requirements and supervision, which leads to that students have certain randomness and no purpose when they look for practicing opportunity and participate in social practice. Students also fail to participate in social practice with the awareness of problems, which leads to that the practical ability of students is not strong and they cannot adapt to the urgent needs of economic and social development.

TABLE III. LIST OF 13 Sports InStitutes TRAINING Program

\begin{tabular}{|c|c|c|c|c|c|c|}
\hline $\begin{array}{l}\text { Curriculum } \\
\text { System }\end{array}$ & $\begin{array}{l}\text { Public } \\
\text { Degree } \\
\text { Course }\end{array}$ & $\begin{array}{l}\text { Basic } \\
\text { Degree } \\
\text { Cours } \\
\text { e }\end{array}$ & $\begin{array}{c}\text { Profess } \\
\text { ional } \\
\text { Degree } \\
\text { Course }\end{array}$ & $\begin{array}{c}\text { Directi } \\
\text { on } \\
\text { Electiv } \\
\text { e } \\
\text { Cours } \\
\text { e }\end{array}$ & $\begin{array}{l}\text { Mak } \\
\text { e-up } \\
\text { Cou } \\
\text { rse }\end{array}$ & $\begin{array}{l}\text { Selectiv } \\
\text { e } \\
\text { Course }\end{array}$ \\
\hline $\begin{array}{l}\text { Beijing Sport } \\
\text { University }\end{array}$ & $\sqrt{ }$ & $\sqrt{ }$ & $\sqrt{ }$ & $\sqrt{ }$ & & \\
\hline $\begin{array}{l}\text { Guangzhou } \\
\text { Sport } \\
\text { University }\end{array}$ & $\sqrt{ }$ & $\sqrt{ }$ & $\sqrt{ }$ & & $V$ & \\
\hline $\begin{array}{l}\text { Harbin Sport } \\
\text { University }\end{array}$ & $\sqrt{ }$ & $\sqrt{ }$ & $\sqrt{ }$ & & & \\
\hline $\begin{array}{l}\text { Shandong } \\
\text { Sport } \\
\text { University }\end{array}$ & $\sqrt{ }$ & $\sqrt{ }$ & $\sqrt{ }$ & $V$ & $V$ & $\sqrt{ }$ \\
\hline $\begin{array}{l}\text { Shanghai } \\
\text { University of } \\
\text { Sport }\end{array}$ & $\sqrt{ }$ & $\sqrt{ }$ & $\sqrt{ }$ & $\sqrt{ }$ & & \\
\hline $\begin{array}{l}\text { Nanjing Sport } \\
\text { Institute }\end{array}$ & $\sqrt{ }$ & $\sqrt{ }$ & $\sqrt{ }$ & $\sqrt{ }$ & $V$ & \\
\hline $\begin{array}{l}\text { Wuhan Sports } \\
\text { University }\end{array}$ & $\sqrt{ }$ & $\sqrt{ }$ & $\sqrt{ }$ & 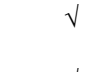 & & \\
\hline $\begin{array}{l}\text { Xi'an Physical } \\
\text { Education } \\
\text { University }\end{array}$ & $\sqrt{ }$ & $\sqrt{ }$ & $\sqrt{ }$ & $\sqrt{ }$ & & \\
\hline $\begin{array}{l}\text { Chengdu Sport } \\
\text { Institute }\end{array}$ & $\sqrt{ }$ & $\sqrt{ }$ & $\sqrt{ }$ & & $V$ & \\
\hline $\begin{array}{l}\text { Shenyang } \\
\text { Sport } \\
\text { University }\end{array}$ & $\sqrt{ }$ & $\sqrt{ }$ & $\sqrt{ }$ & & $V$ & \\
\hline $\begin{array}{l}\text { Capital } \\
\text { University of } \\
\text { Physical } \\
\text { Education and } \\
\text { Sports }\end{array}$ & $\sqrt{ }$ & $\sqrt{ }$ & $\sqrt{ }$ & $\sqrt{ }$ & & $\sqrt{ }$ \\
\hline $\begin{array}{l}\text { Tianjin } \\
\text { University of } \\
\text { Sport }\end{array}$ & $\sqrt{ }$ & $\sqrt{ }$ & $\sqrt{ }$ & & $V$ & \\
\hline $\begin{array}{l}\text { Jilin Sport } \\
\text { University }\end{array}$ & $\sqrt{ }$ & $\sqrt{ }$ & $\sqrt{ }$ & & $V$ & $\sqrt{ }$ \\
\hline
\end{tabular}

\section{OPTIMIZATION ANALYSIS OF SPORTS SCIENCE TRAINING PROGRAM FOR POSTGRADUATES}

Colleges and universities should give full play to its own advantages and establish a service platform for scientific research, optimize the personnel training programs, create the new modes of personnel training and improve the quality 
of personnel training, so as to adapt to the social demands for sports talents of high level.

\section{A. Set Up Training Program According to the First Level Discipline of Physical Education}

Over the years, the adjustment and improvement of "subject and major catalogue" of our country reveals the trend of gradually strengthening the first level discipline. [3] The formulation of sports science training program for postgraduates should be based on the requirements of Introduction of First Level Discipline of Degree Awarding and Personnel Training and the objectives of "double class" construction, abandon the second level discipline setting program, establish and improve the training curriculum system according to the first level discipline, and separately introduce the general situation, connotation and scope of discipline from the three aspects of discipline, major and direction, so as to cultivate the inter-disciplinary and innovative talents, conform to the demands of social development for high level talents of physical education in the background of national strategy.

\section{B. Conform to the Social Demands and Scientifically Formulate Training Objectives}

Combining with the characteristics of discipline, we can formulate sports science training objectives for postgraduates and gradually form the postgraduate training mode adapting to training objectives and centering on postgraduates growth with characteristics of discipline. To refine the training objectives, we should have different orientations for different fields, to make it more specific in expression and more explicit in extension, so as to strengthen the guidance of training objectives and improve the controllability and operability of training programs. On the basis of guaranteeing the training quality, we should emphasize the appropriateness of personnel training and social needs, and make the employment direction clearer. In addition to reflecting ideology and politics and moral cultivation, we should come up with explicit and clear requirements on professional knowledge, scientific research ability, academic ethics and level of foreign language.

\section{Research Direction of Dynamic Adjustment}

There is a lack of effective interactive adjustment mechanism between postgraduate education system and social demands. There is an increasing disparity in high level postgraduates and the needed talents in our economic and social development. [4] With the constant change of social demands, the training quality of postgraduates under different training goals is gradually developing towards diversification. We should stand on the forefront of disciplines, insight the direction of discipline development, condense discipline direction, and pay attention to the significant and far-reaching area in social development, and strive to reflect the forward-looking, progressiveness and cutting-edge. We should try to grasp the mainstream and trend of discipline development, combining with social demands, list 2-6 research directions and the directions of the curriculum in detail according to the major in the curriculum setting of training program. We could make students have a better understanding on the relationship between discipline, major and direction, and make students combine with their research interests to establish research directions.

\section{Enrich the Cultivation Mode}

According to the principle of broad caliber and thick foundation, we should strengthen the innovative ability training of postgraduates and explore and enrich training forms. We should establish some training methods, such as organizing Master Tutor steering group to jointly guide postgraduates, the link of curriculum learning, the breakthrough of key problems and case teaching of frontier research progress and so on. Through case analysis, social investigation, conceptual design and research report and other methods, we can enrich the training methods and assessment methods. For some examination courses for seminars, we can increase the process control efforts and the content will be examined as the evidence of evaluation for the total credits.

\section{E. Establish Quality Standards}

According to The Basic Requirements of Doctor's and Master's Degree of the First Level Discipline, combining with the characteristics of physical education course, we can make the evaluation standard and basis of sports science training quality for postgraduates, and make explicit requirements on the basic knowledge, basic quality, academic ability, academic ethics and the quality standard of thesis of the curriculum that postgraduates should master. We can make a list of sports disciplines which can reflect the academic tradition and dynamic research frontier at home or abroad, such as required readings, selected readings, literature and academic journals, and it can make postgraduates have more pertinence on literature reading and put forward explicit requirements for the reading quantity. We should set up the evaluation criteria of academic papers, pay attention to the depth and difficulty, logical thinking and innovative ideas of the theory, and prominently test the ability of postgraduates to engage in scientific research.

\section{F. Condense Curriculum Content}

As Bobbitt, an American educator, said in Course: "Education is essentially a process of revealing people's potential abilities and it has some special relationships with social conditions, and firstly the goals should be set in accordance with the study of social demands." On the basis of summarizing and sorting out the implementation of current postgraduates training program, institutes should timely adjust and condense the curriculum contents according to the development of discipline, the change of personnel demands and the actual teaching effects of courses. Setting courses based on the first level discipline of physical education reflects the level differences of discipline, major and direction curriculum. According to the system of "public degree course", "basic degree course", "professional degree course", "direction course", "practical training and scientific research training" and "make-up course" to set curriculum, it can enhance the foresight and forwardness of the curriculum 
content and can meet students' individualized choices and individualized development.

\section{G. Strengthen Practice Teaching}

Physical education as a practical subject, students need to strengthen this curriculum through practice after accumulating certain professional knowledge, which can improve students' ability to use knowledge comprehensively. We should positively build mass sports science fitness guidance, sports industry research service, sports events service platform and other practical training platform, so as to enhance the cultivation of students' practical ability and meet the demands of high level talents in sports industry.

\section{CONCLUSION}

In the superposition period of national strategy of national fitness, sports industry and health China, the enrollment scale of postgraduates of sports science has developed rapidly, and education quality has become the focus of colleges and universities and social people of insight. Training program as a programmatic document for postgraduates' teaching work, it determines the quality and level of postgraduate education whether the training program is scientific or not. Only by building an impeccable dynamic adjustment mechanism can we meet the demands of society and effectively offer high level talents guarantee to the development of sports undertakings and sports industry of our country.

\section{REFERENCES}

[1] National Information Consultation and Employment Guidance Center for High Education Institutes, Graduate School of Education, Peking University. Employment Status of College Graduates in China (20092010) [M]. Beijing: Peking University Press, 2011, 139-146

[2] He Zhenxiong. Integrating Different Graduate Cultivation Modes to Meet the Demand of the Society for All Types of Graduates [J]. Academic Degrees and Graduate Education, 2007 (10)

[3] Zhang Chunyuan, Li Jianchuan. Sticking to the First-Level Discipline Development, Improving the Core Competitive Power of Disciplines [J]. Academic Degrees and Graduate Education, 2010, 1: 40-45

[4] Guo Rui. Research on the Training Mode Reform of Postgraduates in the New Area of China [J]. Academic Degrees and Graduate Education, 2013, 5:113-117.

[5] Zhang Wenhui, Lin Jiming. Taking Employment as the Guidance, Developing the Reform of Graduate Course System[J]. Higher Education Forum, 2010 (3)

[6] Zhou Yezhong. Diversified Demand and Reform of Graduate Education Mode [J]. China Higher Education, 2004 (17)

[7] Lei Zhe. Investigation on Training Program of Postgraduate of Physical Education in China [J]. Sports Culture Guide, 2012, 2

[8] Zuo Feilong. Study on Postgraduate Training Programs from the Perspective of the Relationship between Supply and Demand of Sports Science [D]. Master Thesis of Soochow University, 2015

[9] Cao Jian. Mode of Cultivating Postgraduates Majoring in Physical Education [J]. Journal of Wuhan Institute of Physical Education, 2014 (38), 6:122-125 